\begin{abstract}
Др Наташа Милићевић
Институт за новију историју Србије $\quad$ 316.728(497.11)"1941/1944" natasa.milicevic@mts.rs_ https://doi.org/10.18485/ai_san_o_gradu.2018.ch13
\end{abstract}

\title{
ГРАД И ЊЕГОВЕ ГРАНИЦЕ: НОВО ОБЛИКОВАҢЕ ЈАВНОГ ПРОСТОРА У ОКУПИРАНОЈ СРБИЈИ 1941-1944.*
}

У раду се анализирају промене које је, кроз ново обликовање јавног простора, оставила на градове Србије немачка окупација у Другом светском рату. Посебан акценат ставља се на унутрашње и спољне границе, баријере и ограничења путем којих је окупатор омеђавао, преобликовао и контролисао јавни простор градова, пре свега улица као типичних урбаних јавних простора. Преко садржаја, доживљаја и вићења прати се и одговор самих становника на ново дефинисање јавног простора градова и његових граница.

Кључне речи: град, границе, нацистичка окупација, Србија, јавни простор, улице, свакодневни живот.

Рат и нацистичка окупација Србије утицали су на бројне промене у јавном простору српских градова. Видљива је, као и у случају сваке окупације, потреба окупатора да контролише заузети простор и територију. Он то чини наметањем нових правила чиме преобликује и наново омеђава јавни простор. Једном речју, успоставља своју моћ. Она је некада исказана кроз физичка а некада кроз симболичка знамења границе. Војници, жица или стражарска станица су, на пример, кон- 
кретни елементи тог непријатељског присуства. Нешто другачију природу имале су оне мање видљиве границе „унутрашњег простора“ становника градова. Постоје, како то истиче Пјеро Занини ((Piero Zanini), различита значења границе. Она су, каже он, могла да буду не само физичка и политичка, идеолошка или духовна, административна или нормативна, већ и временска и симболичка (Zanini 2002). И у окупираним српским градовима препознају се разне врсте поменутих граница. Оне се могу схватити и називати ограничењима, баријерама, оградама... Биле су видљиве и невидљиве, спољне и унутрашње „границе“. Одредиле су дозвољено и недозвољено понашање становника. Обухватале су читав јавни простор градова, па и улица, као типичних урбаних јавних простора. Али, у исто време, те исте границе су се, преко виталности његових становника, прекорачивале, превазилазиле и рушиле. Неретко и по најскупљу цену, цену живота, али се не признају и одбацују.

Већ на почетку рата и окупације успостављена је нова политичка географија српског простора и српских градова. Наступило је време дубоких и болних промена и за градове и његове становнике. Србија и српски градови подељени су на окупационе зоне под контролом Немачке, Мађарске, Бугарске и Италије. Немачка је завела строгу војну управу над Србијом, контролисала Трепчу, Косовску Митровицу и Банат, који је формално био у стаставу Србије, а фактички у рукама домаћих Немаца (Petranović 1992: 113-114). Остале окупационе силе прошириле су своје границе захватајући значајне делове Србије. Простор Србије је тако сужен на предкумановске границе, односно на време пре 1912. године. Тај простор се на истоку и југоистоку граничио са Бугарском, на северу са Мађарском, на западу и северозападу са Независном Државом Хрватском (НДХ) и на 
југу са Италијом. ${ }^{1}$ Исцртане су нове политичке границе, које су настале као израз међусобна разграничења између самих окупатора и савезника. То је неким градовима дало дугачију димензију, облик и функцију. Градови попут Београда и Шапца повратили су своју ранију улогу градова на граници. Њихова природна граница на реци Сави поново је постала политичка граница, и то овог пута са Независном Државом Хрватском (Kreso 1979: 83). За разлику од њих, Врање, некадашњи погранични град, ушао је у састав бугарске државе, а улогу пограничних градова добили су Бела Паланка и Власотинце (Stojiljković 1989: 65-70). Ова пограничност у условима рата и окупације није носила и раније функције привилегованости у посредовању. Неки од њих, посебно градови у близини бугарске границе, постали су и места озбиљне нестабилности и угрожености за локално становништво. Али и они су, на известан начин, превазилазили те улоге са постепеним немачким препуштањем освојеног простора бугарској војсци. Примера ради, већ почетком 1942, бугарске јединице замењују немачке војне снаге у Лесковцу, Крушевцу, Ћуприји, Јагодини, Алексинцу, а онда и 1943. године и остатак градова јужно од Саве и започињу контролу новозадобијене територије. Они су, додуше, имали само заштитну улогу у осигурању саобраћајних, пре свега же-

1 Рад је настао у оквиру пројекта Срби и Србија у јуіооловенском

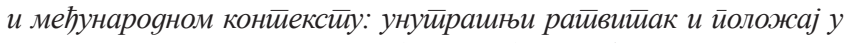
евросйкој/светиској зајеgници, (№ 47027), који финансира Министарство просвете и науке Републике Србије.

Италији је припао највећи део Косова и Метохије, који је она укључила у творевину под називом „Велика Албанија“, Мађарска је окупирала и анектирала Барању и Бачку, а у састав новостворене квинслишке творевине Независне Дражаве Хрватске ушао је од октобра 1941. и простор све до Земуна. У састав Велике Бугарске ушли су источни и јужни делови Србије са пиротским, врањским и деловима лесковачког округ. (Petranović 1994: 111-113) 
лезничких, праваца и привредних објеката због чега су и били под надзором немачких власти (Stojiljković 1989: 75$78,122-123,139-146)$. Ипак, бугарске војне власти су често шириле добијена овлашћења, па су себи додељивале и полицијску власт, спроводиле контролу кретања и путовања становника преузетих градова. ${ }^{2}$

Границе између окупационих зона нису биле непропусне, нити херметички затворене, мада је било и таквих периода. ${ }^{3}$ Оне се озбиљно, иако тешко, контролишу. У почетку је чак омогућено да се десетине, па и стотине хиљада протераних Срба из мађарске и бугарске окупационе зоне или из НДХ склоне у Србију. Углавном се стваpajy, као и код свих граница, гранична места за пролаз, стражарске кућице, граничне страже, царинске службе и захтевају дозволе за пролаз. Дозволе за пролаз и пасоше траже сви за прелазак граница зона и није их лако било добити. ${ }^{4}$ У исто време, границе између окупационих зона биле су за српске становнике и српске власти под окупацијом и извор сталне напетости и непријатељства, па

2 Примера ради, бугарске војне власти нису признавале дозволе за путовање издате од српских власти. Тако становници Куршумлије нису могли да уђу у воз нити да напусте место, ако им дозволе за путовање нису издале бугарске власти, које на то, према договору с немачким властима, нису имале право (Архив Србије (АС), Земаљска комисија Србије за утврђивање злочина окупатора и њихових помагача (Г25), ф-16, Управа полиције у Нишу - Министарству унутрашњих послова, Одељењу државне заштите, 26. мај 1942).

3 Већ средином маја 1941. године немачке власти су тражиле да се „херметички затвори граница“ према Бугарској, како би се спречио шверц динарском валутом, контролисао путнички саобраћај и трговина животним намирницама. То није било лако, с обзиром да је преузети домаћи апарат граничне службе био недовољно бројан (Stojiljković 1989: 66).

4 Архив Југославије (AJ), 103-158-574, Препис извештаја из Каира о приликама у земљи, Лондон, 27. фебруар 1942. 
чак честих оружаних сукоба. ${ }^{5}$ Поменимо тако да се су хрватски војници прелазили на српску територију или су пак пуцали преко Дрине и Саве на српску страну. Тако је крајем 1941. и почетком 1942. године забележено више случајева „прелаза усташа у Шабац“.6 Њихово присуство јесте узнемирило Шапчане, али су много опаснији били оружани напади преко речних граница. Они су били изражени посебно зими, када се река ледила и омогућавала приближавање српској страни. Током фебруара 1942. године примећени су учестали инциденти у којима су усташе пуцале на пролазнике (обичне грађ)ане и сељаке, али и представнике српске власти) преко реке, а који су се кретали путем Београд-Обреновац, који иде уз саму обалу реке Саве. ${ }^{7}$ Дешавала су се и бројна убиства српских избеглица на реци Дрини. Они су покушавали да бежећи од усташке потере препливају реку и склоне се на српску територију. Међутим, усташе су их сустизале и убијале наочиглед и српских граничних служби и сељака из места уз границу.

5 О томе више у Borković, 1979: 239-253.

6 Њихово присуство је изазивало велико узнемирење становника Шабца. Због неовлашћеног прелаза и повреде границе српске власти су их хапсиле, да би их одмах затим немачке власти пуштале и враћале на територију НДХ (Војни архив (ВА), Недићева архива (Нда), 20-1-30, Извештај Окружног начелства округа шабачког - Министарству унутрашњих послова, Одељењу за државну заштиту, бр. 202, 26. јануар 1942).

7 ВА, Нда, 206-1-18, Извештај окружног начелства окуга шабачког о пуцању из Хрватске - Министарству унутрашњих послова, Одељењу за државну заштиту, бр. 1514 од 18. фебруара 1942; Vojinović 1995: 142; Милићевић 2014.

8 Тако је страдало 30-ак жена и деце почетком априла 1942. године, на обали Дрине, у близини места Бјеловац у Босни (Ва, Нда, 20-7-16, Извештај Начелство среза Азбуковачког, о повреди српске територије од усташа пуцањем из машинског оружја и бацача бомби - Министарству унутрашњих послова, Одељењу за државну заштиту, пов. бр. 134, 9. април 1942). 
Није само Београд био одвојен од Земуна стварањем политичке границе, већ је и Панчево изузето из подручја управе града Београда, и припојено Банату. У Панчеву је постојала и царинарница под контролом фолксдојчера. ${ }^{9}$ Тиме је створена и једна нова, додуше, административна граница града, коју опет није било лако заобићи, посебно не за становнике Београда, који су имали имања у Банату. Они су морали да иду пешке преко понтонског моста или су користили лађе, које су по неколико пута дневно прелазиле Дунав. Дозволе за прелаз давале су немачке власти, а за кретање пешке мостом српске полицијске власти. ${ }^{10}$ Због тога су се формирали и илегални прелази преко Дунава. ${ }^{11}$ Дешавало се повремено и да се неки градови нађу под тоталном блокадом немачких и српских контролних власти. Тада је било посебно тешко ући у град, мада није било лако ни изаћи из њега. Блокада се тако појављује као још један назив за границу, којом се нешто спречава и не дозвољава. У њеној основи јесте „непомирљива воља“ која, послужимо се речима Пјера Занинија, „одузима не само простор, већ и ресурсе“ (2002: 76). Главни циљ те „воље“ окупационих власти био је, у повећаним потраживањима у пшеници и потреби да се она обезбеди контролом уноса намирница и ценама на тржишту. Зато је током 1942. године уведена забрана уноса брашна и уопште житарица, меса, сланине, масти и прерађевина од меса у

9 Царинарница је заправо заменила раније постојеће одељење београдске царине (Службене новине, бр. 83 од 25. јуна 1941).

10 Ново време, 20. јун 1941, 6.

11 Уочено је шест главних илегалних прелаза: код Вишњице, Beликог села, Винче, Ритопека, Гроцке - више прелаза, и између Гроцке и Смедерева - више прелаза (Историјски архив Београда (ИАБ), Управа града Београда (УГБ), Специјална полиција (СП), к-141/17, Извештај V кварта УГБ - Управи града Београда, Одељењу специјалне полиције, 25. фебруар 1943). 
бројне градове. Становницима су од немачких и српских трошаринских контрола одузимане намирнице без накнаде, а повремено тек по максимираној цени. ${ }^{12}$ Тада се остајало и без намирница, али и без новца за нова путовања и куповину хране. Међутим, није било и немогуће. Једноставно, тражени су и налажени начини да се блокада пробије, избегне неизвесно добијање дозвола, превазиђе и прескочи наметнута препрека. То је напросто захтевао и наметао сам живот.

Треба поменути да је, у исто време, дошло и до појаве једног важног феномена, који има везе са границама. Са сужавањем простора Србије дошло је до растезања времена, па је становницима градова требало много више времена, него у миру, да стигну од једног до другог града. Чинило се да путовање траје бескрајно дуго. Нема потребе наглашавати проблеме које су за путнике представљали устаници и ратни окршаји. Мање очигледни, али једнако мучни и тешки, били су проблеми настали због нових граница и промене врсте пута и превозног средства. Грађани Шапца и Београда, примера ради, нису могли после повлачења границе са Независном Државом Хрватском да путују возом јер је он полазио са станице из села Кленак, које је припало НДХ. Зато су били принуђени да током окупације путују теретном лађом. А она је ишла директно по већ одавно постојећој природној граници, која се претворила у политичку. То joj је због непријатељства суседа са леве стране давало значење опасности и неизвесности. Томе треба додати и замке самог путовања. Лађе су редовно биле претрпане путницима, тако да је било тешко на њима проводити и по дванаест сати, колико је, на пример, требало да се

12 Милићевић и Никодијевић 2011: 214, Забелешка од 8. маја 1942; Бабовић 2005: 381, Забелешка од 6. септембра 1942. 
пређе пут од 105 км између Београда и Шапца. ${ }^{13}$ А некад се дешавало и да се теретни бродови насукају. Тада је пут постајао још дужи; иако се простор сузио, чинило се да се раздаљина повећавала, а тиме и време. У случају ниског водостаја, ишло се запрежним колима преко Обреновца, која су се већ од почетка окупације врло скупо плаћала. ${ }^{14}$

Посебна врста промене одигравала се у физичком изгледу српских градова. Многи од српских градова изменили су се у великим разарањима како у немачким и савезничким бомбардовањима, тако и у одмаздама окупатора. Угрожена је не само њихова функционалност и естетика, већ и њихово трајање. Рушене су предратне границе њиховог физичког постојања. Поменимо, ради илустрације, по ко зна који пут Београд. Његове улице су у бомбардовањима често биле разрушене до непрепознавања. Нестале су бројне кафане, стамбене или јавне зграде. Неке од њих су својом постојањем и симболиком дефинисале урбани јавни простор. Савременицима је у немачком бомбардовању посебно тешко пало спаљивање Народне библиотеке на Косанчићевом венцу, која током окупације а ни касније није обновљена, нити је то могла бити; само обнављање је започело на другој локацији, али заправо није се могло повратити нешто што је било непроцењиво сведочанство у историјском трајању српског народа. ${ }^{15}$ Тиме је

13 М.С, „Кад се Шабац претвара у Београд“, Срӣски нароg, 24. октобар 1942, 9; Московљевић, рукопис, Забелешка од 14. новембра 1943.

14 Бабовић 2005: 68, Забелешка од 15. маја 1941; Исто, 123-124, Забелешка од 10. септембра 1941.

15 Пензионисани чиновник Драгутин Ј. Ранковић је, попут многих својих суграђана, помогао њену обнову целом својом „књижницом“, која је преостала после бомбардовања његове куће. Била је смештена, како је записао, у „неудобну кућу“ у Француској улици бр. 36 (Милићевић и Никодијевић 2011: 69, Забелешка од 5. септембра 1941; Исто, 353-354, Забелешка од 13. октобра 1942). 
град изгубио један просторни и духовни оријентир. Забележено је од стране једног сведока и да је тада нестала читава једна улица у близини Јованове пијаце. ${ }^{16}$ Он каже: „Изгледа чудновато, али тачно да је услед бомбардовања 6-8. априла о.г. цела једна улица уништена. Више на лицу нема Косачине улице, некадањег Катулиног сокака. [...] Цео тај крај, који је у рушевинама, биће регулисан “.17 Нестала је тако, бар за извесно време, још једна граница у простору и најављено настајање друге, за коју не знамо да ли је током немачке окупације спроведена. Оно што је сигурно јесте да су бројне улице рашчишћене због потреба окупатора за смештајем и несметаним кретањем, али су многе поново страдале у савезничким бомбардовањима током 1944. године. Поред Београда, бомбардовани су још и Лесковац, Ниш, Крагујевац, Нови Сад и неки други мањи градови. Посебно велике материјалне и људске губитке доживели су Ниш и Лесковац. У Лесковцу је био погођен сам центар града са стамбеним блоковима. Страдало је, према проценама, између 1.000 и 2.000 људи. ${ }^{18}$ Смедерево, које се такође нашло на удару савезника, већ је у првој ратној години (јуна 1941. године) доживело је велику трагедију када је експлодирало складиште муниције у Смедеревској

16 Пијаца у Господар Јовановој улици била је једна од седам пијаца у Београду, на којима је је било дозвољено сељацима да продају своје производе. Било је још осам пијаца, где је продаја могла да се обавља тек после прибављања одобрења о хигијенско-санитарним приликама (Службене новине, бр. 107 од 16. септембра 1941, Правилник о реду на пијацама Општине града Београда; Милићевић и Никодијевић 2011: 27).

17 Милићевић и Никодијевић 2011: 74, Забелешка од 13. септембра 1941.

18 Истраживачи се слажу да се никада неће моћи тачно утврдити број страдалих цивила. До средине деведесетих година 20. века утврђено је да је погинуло 819 цивила (Павловић и Трајковић 1995: XCL). 
тврђави. Тада је практично пола града нестало у рушевинама, а погинуо је и велики број смедеревских грађана (Petranović 1992: 112). Преживели су били принуђени да, до обнове града, потраже склониште код рођака и пријатеља у селима у близини града.

Покретање устанка, сукоби са непријатељем, али и међусобно супротстављање антифашистичких покрета изменили су лик градова и варошица који су се налазили на линији њихових дејстава (Чачак, Краљево, Пожега, Ужице, Шабац, Горњи Милановац). Можда је међу њима највеће физичко мењање ипак доживео Горњи Милановац, који је од стране Немаца спаљен готово до темеља у октобру 1941. године (Тимотијевић и Давидовић 2002: 243). Сурова освета окупатора сагледива у тоталном уништавању и брисању једног града, била је и освета за нарушена правила створена на почетку освојеног простора. Она је истовремено требало да покаже и да не постоје границе којих ће се придржавати у одбрани тог простора и сопствене безбедности. То је окупатор наговестио и показао предузимањем и одмаздом над покореним становништвом. Омазде су често биле унутар граница града. Видљиве на његовим улицама, оне су постале за становнике градова и специфични гранични простори сећања и подсећања. Биле су, иако мучни и тескобни, и својеврсни оријентири у њиховом кретању окупираним улицима. Места и призори који се не заборављају и који опомињу. С гледишта окупатора, прича и препричавање страшног догађаја, какво је свака одмазда, требало је и да унесе страх и осигура покорност. ${ }^{19}$

19 Овде само подећамо на добро позната места одмазди, попут вешања на Теразијама или стрељања у Краљеву и Крагујевцу. На тај начин желели смо да пре свега укажемо на важност тако створених граница у јавном простору града. 
Можда увођење и наметање граница, ограда и баријера, тек наговештено поменутим страшним призором, које је спровео окупатор у простору улице, као типичном јавном простору градова, пружа најбољу слику како се јавни простор и сам град, градски живот преобликују у складу са сопственим потребама и интересима. Већ је само присуство окупаторских војника на улицама, као и у случају других окупираних државних простора, сведочило ко је господар а ко потчињени, ко је окупатор а ко окупирани, ко је пријатељ а ко непријатељ тог простора. У првим данима окупације грађанима се чинило да су њихове улице и градови „пренатрпани“ немачком војском. ${ }^{20}$ Шабачки прота Бабовић је забележио: „Уопште нико се не воли без потребе кретати улицама, јер су их прекрили немачки војници, а као нама нико не брани“.21 Првобитан страх грађана постепено је попустио, али није нестао и потрајао је целу окупацију. За Иву Андрића страх је крајем 1942. године још увек свеприсутан. Он пише: „Страх је свуда и несаница општа. Мало ко зна заправо чега се боји, а у већини случајева тај страх је неоправдан или претеран, али поред свега тога људи иду са унезвереним погледом, бирају споредне улице и ноћу дрхте пре него заспу и буде се у тами, пре времена, сувих уста, са јауком и са осећајем да су са обе ноге у клопци“ (Живојиновић 2003: 13). Било је, посебно на почетку окупације, и супротних осећања и понашања. Становници градова одбијали су да се приликом кретања улицама склоне немачким војницима и официрима и тако им укажу

20 АЈ, 103-5-51, Извештај Милоша Секулића о стању у Југославији - Комитету Министара за пропаганду, пов. 6р. 257, Лондон, 19. новембар 1941.

21 Бабовић 2005: 55, Забелешка од 17. априла 1941. 
поштовање. И не само то. Остало је забележено да им становништво „чак шта више дрско закрчава пут“.22 Због тога је било и јавних упозорења становништву. Постепено је почело и упознавање с непријатељем. Један савременик је записао и прве утиске у којима Немце види као „фин и културан свет“, док је други примећивао њихову младост, која их је „изненадила““ ${ }^{23}$ У сваком случају, успостављена је „граница“ између окупатора и окупираних, између немачке и српске власти, између српске власти и становништва, која се преко бројних забрана и ограничења видела у свакодневном животу грађана у простору улице.

Велику промену у свакодневици становника у простору улице донело је увођење „временске границе“ у слободи кретања. Она је уведена одмах на почетку окупације и сагледива је кроз разна ограничења у слободи кретања у јавном простору. Била је, као и свуда у Европи, на снази током читавог периода окупације. Одмах на почетку окупације, поред завођења немачког рачунања времена с једним сатом унапред, забрањено је становницима излажење из кућа и кретање улицама од седам сати увече до пет сати ујутро. Становници градова нису могли да се као раније, осим са специјалним дозволама, нађу на улици после поменутог времена, да се затекну у кафани или на неком другом јавном месту које није било њихова кућа. Због тога је и већина грађана морала да све своје свакодневне активности прилагоди дневном ритму живота. Може се слободно рећи да је простор улице био простор у коме су грађани „живели само дању“ и да је дом био простор у коме су „живели ноћу“. „Граница“ за слободно улично кре-

22 Ойшичинске новине, 23. мај 1941, 3; Исто, 24. мај 1941, 3; Исто, 25. мај 1941, 3.

23 Николић 2002: 16; Бабовић 2005: 52, Забелешка од 15. априла 1941. 
тање током окупације није била у свим градовима иста, и зависила је од тренутне војно-безбедносне процене окупаторских власти у неком подручју и граду. У време устанка то временско ограничење је погоршано, па је у Аранђеловцу почињало од 17 сати. ${ }^{24}$ Касније је, после смиривања стања, померена на девет или десет сати увече. За њено кршење, посебно, у првим данима окупације, кажњавало се и стрељањем. ${ }^{25}$ Због тога су простори улице ноћу били углавном пусти. Чинило се, како описује Иво Андрић, почетком фебруара 1943. године, да после почетка полицијског часа „варош изумире, већина људи се затвори у куће, као на силу покојници, а мањина, тј. Немци и они од наших који имају немачки аусвајс, пролазе улицама као зле и срамотне авети, оштро им одјекује корак, а у бахатости тих корака осећа се снебивање и скривена несигурност“ (Поповић 2009: 152). Још гора ситуација била је на улицама градова у време рестрикција струје, која се готово сваке зиме понављала. Утисак савременика је да су градови и улице, због мрака, пружали ,јадан изглед“. У мањим градовима гасила се улична расвета, осим на раскрсницама, док је у великим градовима упаљена била свака десета

24 АЈ, 382-1-3, Извештај Краљевског посланства у Лисабону о приликама у Југославији - Министарству иностраних послова КЈ, Лисабон, 25. септембар 1941.

25 Бабовић 2005: 134, Забелешка од 16. септембра 1941. Према једном другом извору, у првих неколико недеља после окупације због кршења дозволе о забрани кретања после полицијског часа, налажени су лешеви по улицама са прикаченим цедуљама на којима је писао „Закаснио 2 до 3 минута“. Међутим, мишљења смо, јер то не поткрепљују други извори, да су такве вести израз претераног страха и да су препричавањем добиле екстреман вид. Ни немачка документа, у којима се врло прецизно бележило свако убиство, не потврђују тачност ових сазнања. (АЈ, 103-27177, Извештај о стању у Југославији после окупације инг. Бранка Шаина - Милетића, Лисабон, 14. децембар 1941). 
лампа. ${ }^{26}$ Зато се често боравило у мраку или се морала употребити свећа, која је била врло скупа. ${ }^{27}$ Насупрот њима, тамо где су становали Немци било је другачије. Прозори су у тим кућама били добро осветљени и замагљени од топлине, а чули су се гласно и радио-апарати. ${ }^{28}$ Становници градова су, без могућности да изађу из својих кућа, рано ишли на спавање. Неки су били мишљења да се „више спава него икада пре рата“ и да су „људи отупели од дугог спавања“. 29

Због тога су становници градова морали да све своје свакодневне активности у простору улице прилагоде дану. Али и дозвољено кретање улицама по дану није увек било ни једноставно ни лако. Неке улице или делови улица добили су „границе“ и били су забрањени за кретање или су их сами грађани обилазили. То се посебно односи на просторе испред зграда које је немачка власт узела за средишта својих установа. Становници Београда нису смели да пролазе, на пример, поред Народне скупштине, где се налазио Немачки војни заповедник, Ратничког дома где је био смештен Гестапо, итд. Улица Змај Јовина, која се пружала поред Ратничког дома, била је потпуно забрањена за кретање. ${ }^{30}$ Сличан случај је и са Улицом Бријановом, која

26 Бабовић 2005: 529, Забелешка од 16. децембра 1943; Михаиловић 2004: 55, Забелешка од 8. марта 1943.

27 Милићевић и Никодијевић 2011: 148, Забелешка од 16. фебруара 1942.

28 Бабовић 2005: 529, Забелешка од 16. децембра 1943.

29 Михаиловић 2004: 55, Забелешка од 8. марта 1943.

30 Милићевић и Никодијевић 2011: 100-101, Забелешка од 24. децембра 1941. 
се простирала од Краља Александра до Косовске. Она је била, како сведочи савременик, „сва обрасла травом“ jep је био забрањен сваки пролаз. ${ }^{31}$ Поред тога, били су ограђени летвама или бодљикавим жицама и тротоари улица испред поменутих зграда, као и испред установа или зграда значајних за немачку власт под окупацијом. ${ }^{32}$ Испред истих постављени су бункери, као и на другим местима битним за безбедност и одбрану освојене територије. ${ }^{33}$ У исто време, немачки окупатор је своју доминацију у јавном простору у сваком граду обележио и истицањем застава, исписивањем великог слова „V“ (Victoria/Победа) и кукастог крста на зидовима лако уочљивих зграда. И улица је коришћена. На асфалту су масном белом бојом исписане разне пароле. Становници Шапца су, на пример, у време годишњице мартовских догађања 1943. године газили преко написа „25. март прави домаћин, 27. март роб туђину, 25. март пружио си руку суседу, 27. март ударио му нож у леђа и 25. март подизање, 27. март пад, 25. март борио си се за интересе Србије, 27. март борио си се за интересе непријатеља.... ${ }^{34}$ Подразумева се да је исто било забрањено за окупиране становнике градова.

Између становника и окупатора у уличном простору српских градова уведена је „граница“ и у погледу саобраћајних средстава. Окупатор је реквирирао све аутомобиле, па су становници све чешће користили бицикл. Почетком јуна 1941. рачунало се да је кори-

31 Исто, 300, Забелешка од 30. јула 1942.

32 Исто, 456, Забелешка од 17. фебруара 1943.

33 Исто, 355, Забелешка од 14. октобра 1942; Исто, 404, Забелешка од 24. децембра 1942.

34 Бабовић 2005: 452-453, Забелешка од 29. март

1943. 
сти да гости сваки двадесет пети Београђанин. ${ }^{35}$ У исто време тражило се од становника да поштују саобраћајне прописе, па су постављени и специјални делегати немачке војске са саобраћајним сигналом у руци, који су бринули о реду на улици, односно о прелазу улице на предвиђеним местима, о „непотребном“ задржавању на тротоарима, посебно на угловима улица и сл. ${ }^{36}$ Иако је, истине ради, та врста захтева била и у интересу српских грађана, радило се о потреби да се немачки камиони и аутомобили безбедно и несметено крећу улицама. Посебна врста „границе“ успостављена је унутар превозних средстава. Она се посебно уочавала у трамвајима, тамо где су они постојали, као на пример у Београду и Нишу. У трамвајима су предњи делови, раније намењени за чиновнике, под окупацијом били резервисани за Немце. Чиновници су изгубили посебан третман, па су, као и остали становници, морали да се возе у задњем делу трамваја. ${ }^{37}$ Међутим, та „граница“ је често нарушавана управо од Немаца. Неретко се догађало да је део предвиђен за Немце остајао празан или полупразан, док су немачки војници улазили на задњу платформу и заузимали место осталим путницима. ${ }^{38} \mathrm{~A}$ било је и случајева да путнике избаце напоље. ${ }^{39}$ Овде је

35 Ново време, 14. јун 1941, 5.

36 Ойшишинке новине, 22. мај 1941, 3; Исто, 26. мај 1941, 3 .

37 Ойшииинске новине, 30. април 1941, 3; Божовић 1998: 55.

38 ИАБ, Општина града Београда (ОГБ), к-215, ф-12-614/4, Извештај Дирекције трамваја и осветљења - Кабинету Господина председника Општине града Београда , бр. 26904, 13. јун 1941.

39 AJ, 103-27-177, Извештај Краљевског посланика 
„граница“ представљала израз надмоћи окупатора над окупираним. С друге стране, и припадници српске оружане силе, попут добровољаца и четника, улазили су у предњи трамвајски простор предвиђен за немачку војску. Они су тако покушавали да „превазиђу“ постављену „границу“, али су, у исто време, стварали нову, која их је одвајала од суграђана. Дешавало се неретко да вређају и прете, посебно саобраћајним службеницима. Забележено је тако да је један наредник добровољац, уз непристојне речи, ударао пушком о под и истицао да кочничара „може убити, а да ником не одговара“. То је речито сведочило о њиховој бахатости и уверењу у сопствену предност у односу на остале суграђане због припадности оружаној сили. ${ }^{40}$

Српска власт је, под надзором немачке окупационе власти, поставила разлику у кретању улицом између млађих и старијих становника. Наиме, она је током 1942. године забранила омладини шетњу улицама и одлазак на корзо. Корзо је и даље представљао за омладину оно што је био и пре рата, место сусрета и размене мисли и информација, али је у виђењу представника српске власти био место „бескорисних шетњи“ и нерада. Због тога га је требало ограничити, ако не и укинути. За оне који су кршили забрану претило се затвором

при Светој столици - Министарству иностраних послова, Лисабон, 23. новембар 1941.

40 ИАБ, ОГБ, Административно одељење, к-215, ф-12-151/41, Акт Дирекције трамваја и осветљења о изгредима добровољаца у трамвајима - Председнику градске општине, бр. 57483, 11. новембар 1941; Исто, к-214, ф-11-286/41, Захтев Градског поглаварства, Правно одељење о сукобима четника у трамвајима Главном штабу четника, бр. 19610, 24. октобар 1941). 
и принудним радом. ${ }^{41}$ Ипак, омладина није, како се надала власт, и поред честих рација полицијских патрола и спроведених кажњавања, престала да посећује корзо. Она се, углавном, досетила, па је из једне улице прелазила у другу улицу. ${ }^{42}$

Међутим, слободно кретање становника градова у простору улице преко дана било је посебно нарушавано честим полицијским проверама њиховог идентитета. „Граница“ овде није уочљива на први поглед, али постоји и о њој се може говорити као о „граници идентитета“. Она је, с гледишта окупационе и домаће власти, кроз доказ о идентитету, односно лична документа, раздвајала „исправне“ од „неисправних“ грађана. Обавезно поседовање личне карте („легитимације“) и пријаве боравка није увела окупациона ни домаћа власт под окупацијом, већ су били саставни део грађанског живота и пре рата. Оно што се променило под окупацијом је велики значај који су сада та документа добила у животу грађана. О томе пишу сви савременици. Без њих они нису могли да изађу из куће, па ни да задовоље основне свакодневне потребе. А и онда када су их имали често се догађало да их не штите од могућих проблема. Нарочито велики значај личне карте добијају после устанка, када је у целој земљи спроведено њихово издавање или ревизија (Божовић 1998). Трагало се за устаницима, комунистима, али и преосталим Јеврејима.

41 Корзо није забрањен у исто време у сваком граду. Примера ради, у Крагујевцу је забрана „бесмислених шетњи“ уведена у јануару 1942. године, у Београду у марту 1942. године и то у периоду између 11.30 и 13 и 17.30 и 20 сати, у Шапцу, такође, почетком марта 1942. године, а у Крушевцу у децембру 1942. године, где је забрана изласка на корзо обухватила све становнике (Обнова, 16. јануар 1942, 8; Ново време, 8. март 1942, 7; Исто, 20. децембра 1942, 4; Бабовић 2010: 132; Божовић 2003: 138)

42 Бабовић 2010: 132; Забелешка од 4. марта 1942. 
Провере су били свакодневне. Дешавало се да патроле заустављају поједине становнике по више пута на дан. ${ }^{43}$ Због тога је један грађанин констатовао: „Дошло време да човек не сме из куће да изађе“. ${ }^{44}$ У непосредној вези са границама идентитета је и успостављање видљивог идентитета кроз присуство „расне границе“ у простору улице. Видљива је пре свега у првој години окупације. Она је, у складу са расном политиком окупатора, издвојила, као друштвено непожељне елементе, припаднике јеврејске и ромске заједнице. Окупатор им је, као и другде у Европи, наметнуо, као знак физичког распознавања, обавезно ношење жуте траке са натписом „Јеврејин“ и „Циганин“. Жута трака била и „граница срамоте“ и њихова „лична карта“, која их је лишавала свих права које су имали остали српски становници „аријевци“. ${ }^{45}$ Јевреји су, за разлику од Цигана који су се налазили на друштвеној маргини, припадали српском грађанству, и у предратном периоду били су интегрисани у политички и друштвени живот земље. Нису се ни по чему, осим по вероисповести, издвајали од осталих српских грађана. Међутим, нацистичка окупација их је, као што смо рекли, искључила из редова становника Србије и грађанства, као „аријеваца“. У исто време, овим другима се забрањивало да са њима разговарају и помажу им. ${ }^{46}$ Савременици су забележили и празнину

43 Милићевић и Никодијевић 2011: 174, Забелешка од 14. марта 1942.

44 Исто: 278, Забелешка од 2. јула 1942.

45 О томе више у Божовић 2004; Божовић 2003; Pisari 2014.

46 АJ, 103-5-51, Извештај Милоша Секулића о стању у Југославији - Комитету Министара за пропаганду, Лондон, пов. бр. 257 од 19. новембра 1941; АJ, 370-17-56, Извештај наредника-пилота Симе Миливојевића о стању у Југославији, Цариград, 13. мај 1941; Исто, 370-17-56, Извештај Врховног рабина др И. Алкалаја о последњим догађајима у Југославији, Анкара, 14. јул 1941. 
која се осетила у одсуству Рома на улицама. Шабачки прота Бабовић је примећивао да је сада била другачија прослава Ђурђица. Он каже: „Још нам мањка једна ствар из минулих лепих свечарских дана - а то су наши Цигани свирачи. Нема их више да свирају. Или су побијени или у лагеру. Пријашњих дивних дана о славама крстаре улицама, гледају где је свећа и улазе. Из свих улица разлеже се кроз ладни ваздух свирка“. ${ }^{47}$

У исто време, „границе“ која је окупатор наметао индиректно и директно су подстицале рушење, неких, углавном скривених и другима непознатих, „граница унутрашњег простора“ становника градова. Становници градова, пре свега припадници грађанских слојева, под притиском очувања сопственог живота и живота породице, предузимали су и радње којих су се раније стидели. Примећивало се да се угледни људи више не стиде да „носе џакове главним улицама и да се наједу бела лука...“. ${ }^{48}$ Међутим, то није ишло баш лагодно, без освртања да ли у близини има познаника. Углавном на ту задршку у понашању ретко ко је тада обраћао пажњу. Већина је са знатижељом гледала шта се налази у џаку. Чак би се пре могло рећи да је тада на дело ступила завист, што се има нешто што они сами немају. ${ }^{49}$ То је на директан начин сведочило о моралним искушењима, измени њиховог друштвеног положаја и, у крајњем следу, промени границе њиховог предратног грађанског идентитета.

Ново обликовање јавног простора предузето од окупатора мењало је садржај, доживљај и виђење градова и њихових граница у окупираној Србији од стране његових становника. Тај простор није био више про-

47 Бабовић 2005: 167, Забелешка од 16. новембра 1941.

48 Михаиловић 2004: 55, Забелешка од 8. марта 1943.

49 Милићевић и Никодијевић 2011: 44. 
стор којим су могли слободно да се крећу, друже и размењују мисли и робу, већ простор у коме је доминирала граница принуде, контроле и надзора, али и простор у коме је сам живот често рушио, потискивао и превазилазио границе и ограничења.

\section{Извори и литература}

\section{Необјављени извори}

Архив Југославије. Фондови: Емигрантска влада Краљевине Југославије (103)

Архив Србије. Фондови: Земаљска комисија Србије за утврђивање злочина окупатора и њихових помагача (Г25)

Војни архив. Фондови: Недићева архива (Нда); Емигрантска влада Краљевине Југославије (170).

Историјски архив Београда. Фондови: Управа града Београда (УГБ); Општина града Београда (ОГБ)

\section{Објављени извори}

Бабовић, Григорије-Глиша. Дневник 1941-1945. Рума - Шабац: Српска књига- Глас Подриња, 2005. Штампано.

Бабовић, Григорије - Глиша. Летиойис Шайц̧а 1933-1944 (прир. Сања Петровић Теодосијевић), Београд: Институт за новију историју Србије - Шабац: Библиотека шабачка, 2010.

Vojinović, Aleksandar. NDH u Beogradu. Zagreb: Naklada Pavičić, 1995. Štampano. Живојиновић, Бранимир (прир). „Две бележнице Иве Андрића (Бележница бр. II и Мали нотес цветних корица)“. Свеске Заяужбине Иве Анgрића 20. Београд: 2003, 7-49. Штампано.

Михаиловић, Аритон. Усйомене из окуйације (1942-1944), Београд: Народна књига, 2004. Штампано. 
Милићевић, Наташа и Никодијевић, Душан (прир.). Свакоgневни животи йоg окуйацијом 1941-1944. Искусииво јеgної Беоірађанина. Београд: Институт

за новију историју Србије, 2011. Штампано.

Павловић, Момчило и Трајковић, Верољуб. Савезничко бом-

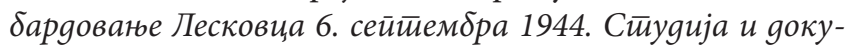
ментии. Лесковац: Народни музеј - Београд: Институт за сваремену историју, 1995. Штампано.

\section{Штампа и периодика}

Ново време

Срйски нароg

Службене новине

Обнова

\section{Литература}

Божовић, Бранислав. Беоіраg ӣog комесарском уйравом 1941. Београд: Институт за савремену историју, 1998. Штампано. Божовић, Бранислав. Сиеецијална йолищија у Беоіраgy 19411944. Београд: Српска школска књига, 2003. Штампано.

Божовић, Бранислав. Сӣраgаюе Јевреја у окуйираном Беоipagy 1941-1944, Београд: Српска школска књига, 2004. Штампано.

Borković, Milan. Kontrarevolucija u Srbiji: kvinsliška uprava 1941-1944. Knjiga prva (1943-1944). Beograd: Sloboda, 1979. Štampano.

Zanini, Pjero. Značenja granice: prirodna, istorijska i duhovna određenja. Beograd: Clio, 2002. Štampano.

Исић, Момчило (прир.). Московтевић, Милош. Дневник 1916-1968. Књ. 4, рукопис.

Kreso, Muharem. Njemačka okupaciona uprava u Beogradu 1941-1944 (sa osvrtom na centralne okupacione komande $i$ ustanove za Srbiju, Jugoslaviju i Balkan) Beograd: Istorijski arhiv Beograda, 1979. Štampano.

Милићевић, Наташа. „Јавност у Србији о Независној Дражави Хрватској 1941-1944“. 
Зборник Матиице срйске за истиорију 89 (2014): 73-89. Штампано.

Николић Коста. Се̄рах и наgа у Србији 1941-1944. Свакоgневни живой йоg окуйаиијом. Београд: Завод за уџбенике и наставна средства, 2002. Штампано.

Petranović, Branko. Srbija u Drugom svetskom ratu 1939-1945. Beograd: Vojnoizdavački i novinski centar, 1992. Štampano.

Pisari, Milovan. Stradanje Roma u Srbiji za vreme Holokausta. Beograd: Forum za primenjenu istoriju, 2014. Štampano.

Поповић, Радован. Анgрићева йријайельсивв. Београд: Служебни гласник, 2009.

Stojiljković, Miroslav. Bugarska okupatorska politika u Srbiji 1941-1944. Beograd: Institut za savremenu istoriju, 1989. Štampano.

Тимотијевић, Милош и Давидовић, Горан. Затиамғена ӣро-

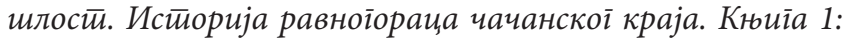
У йламену устианка: райна 1941. іолина. Чачак: Народни музеј и Међуопштински историјски архив - Горњи Милановац: Музеј рудничко-таковског краја - Краљево: Народни музеј, 2002. Штампано.

Др Наташа Милићевић

\section{ГРАД И ЊЕГОВЕ ГРАНИЦЕ: НОВО ОБЛИКОВАҢЕ ЈАВНОГ ПРОСТОРА У ОКУПИРАНОЈ СРБИЈИ 1941-1944}

Градови су у условима рата и окупације Србије доживели драматичне промене. Неки су претрпели ратна разарања, други су у зависности од окупационе зоне под коју су потпали мењали демографску слику (протеривања, одвођења у заробљеништво, одмазде и стрељања), трећи су страдали у ратним окршајима и сл. Било је и оних који су, попут Шапца, добили поново улогу пограничних градова. У исто време, окупатор је јавним просторима, попут улица, као типичних урбаних јавних 
простора, наметнуо многе видљиве и невидљиве границе, које су одредиле дозвољено и недозвољено понашање становника. Уведне „границе“ у јавном простору градова биле су како физичке, политичке, идеолошке, духовне, административне, нормативне, тако и временске и симболичке. Тиме је окупатор настојао да организује простор, да га преобликује, прилагоди себи и контролише. То је, у исто време, значило и да је регулисао и контролисао свакодневни живот урбане друштвене зајединце. Већ је само присуство окупаторских војника на улицама сведочило ко је господар а ко потчињени, ко је окупатор а ко окупирани, ко је пријатељ а ко непријатељ тог простора... На ту очиту границу између „њих“ и „нас“ надовезале су се многе: временска граница за слободно и забрањено кретање (полицијског часа), која је померила доживљај времена, рада или доколице, расна граница, која је издвојила дојучерашње суграђане у посебну групу, физичка граница, која је потпуно забранила кретање појединим деловима улица од важности за окупатора, али и скривена „граница унутрашњег простора“ становника одређена страхом или ранијим положајем у друштву и сл. Ново обликовање јавног простора предузето од окупатора мењало је садржај, доживљај и виђење не само улица, већ и градова и њихових граница у окупираној Србији од стране његових становника.

Кључне речи: град, границе, нацистичка окупација, Србија, јавни простор, улице, свакодневни живот. 